\title{
ONE FLEW OVER THE CUCKOO'S NEST: THE CHRONICLES OF STIGMA AND A PROPOSED SOCIO-COGNITIVE-EMOTIONAL-BEHAVIORAL MODEL FOR UNDERSTANDING ITS GENESIS IN COVID-19
}

\author{
Kumari Rina ${ }^{1}$, Vikas Menon ${ }^{2}$ \& Susanta Kumar Padhy ${ }^{1}$ \\ ${ }^{1}$ Department of Psychiatry, All India Institute of Medical Sciences (AIIMS), Bhubaneswar, Odisha, India \\ ${ }^{2}$ Department of Psychiatry, Jawaharlal Institute of Postgraduate Medical Education \& Research (JIPMER),
} Puducherry, India

received: 5.1.2021;

revised: 14.3.2021;

accepted: 7.4.2021

\begin{abstract}
SUMMARY
Stigma is a convoluted interaction between history, sociology, psychology, medicine, anthropology, and politics. Often, stigma is inter-twined at cognitive-emotional-behavioral level with a socio-cultural-economic-political milieu and hence distinct from prejudice, discrimination or, stereotypy. Stigma against diseases as a concept has evolved and has differed among various illnesses. At this time of humanitarian crisis, it is prudent to understand the concept, elements and models of stigma to tackle stigma against COVID-19 instrumentally. Stigma against COVID-19 can be partially extrapolated from various models described in psychiatry for mental illness. We propose an integrated socio-cognitive-emotional-behavioral model of stigma to conceptualize and understand the stigma against COVID-19, a matter of immense public health significance.
\end{abstract}

Key words: stigma - stigmatized - models of stigma - COVID-19-pandemic - stigma in COVID-19

\section{INTRODUCTION}

From 1720-2020, COVID-19 is among the four hardest-hitting pandemics in history of mankind (Gupta 2020). Infectious diseases are the most stigmatized illnesses (Earnshaw \& Quinn 2013). Stigma, prejudice, and discrimination associated with infectious diseases have ravaged humanity. The word stigma comes from Greek 'steizen' referred originally to a mark or brand on slaves or traitors (Goffman 1963). At an individual level, the negative consequences of stigma spawn into social ostracism, diminished self-esteem, self-confidence and, selfefficacy; feeling of shame, guilt and embarrassment, precipitating or worsening of mental illness (like anxiety, depression, post-traumatic stress disorder, substance abuse, suicide rate), reduced quality of life, influence healthcare-seeking decisions and behaviors; participation and treatment adherence (Türközer \& Öngür 2020, Corrigan et al. 2014). They also govern outcomes in terms of the availability of healthcare services. It undermines the government's efforts on policies, legislation, jurisprudence and implementation on a large scale and may prolong infection transmission (Corrigan et al. 2014, Stangl et al. 2019). Although stigma is overweighed by criticism, it might have a beneficial and adaptive evolutionary role in disease avoidance. The universal 'unitary theory' of stigma is lacking (Smith 2002). Stigma, its various elements, and models have been proposed in the literature in the past.

\section{CONCEPTUALIZING STIGMA AND ITS ELEMENTS}

The pioneering work of Erving Goffman, 1963 and Allport, 1958, sprang research in stigma. Prejudice is defined as "an aversive or hostile attitude toward a person who belongs to a group, simply because he belongs to that group, and is therefore presumed to have the objectionable qualities ascribed to the group" (Allport 1958). Their work portrayed negative attitudes, discrimination, and biased treatment towards disadvantaged groups. Crocker et al. 1998 emphasized the 'devaluation of the stigmatized individuals' possessing (or believed to possess) some attribute, or characteristic conveying a social identity in a particular 'social context'. Experts have cited three main components of stigma. These are authoritarianism, fear and exclusion, and benevolence (Corrigan \& Miller 2004, Brockington et al. 1993, Farina 1998). Thornicraft et al. 2007, advocated three elements of stigma, as ignorance (problem of knowledge), prejudice (problem of attitudes), and discrimination (problems of behavior). Figure 1 conceptualizes stigma and its elements (Goffman 1963, LeBel 2008, Watson \& River 2006, Ritscher et al. 2003, Mak et al. 2008, Rössler et al. 2016). 

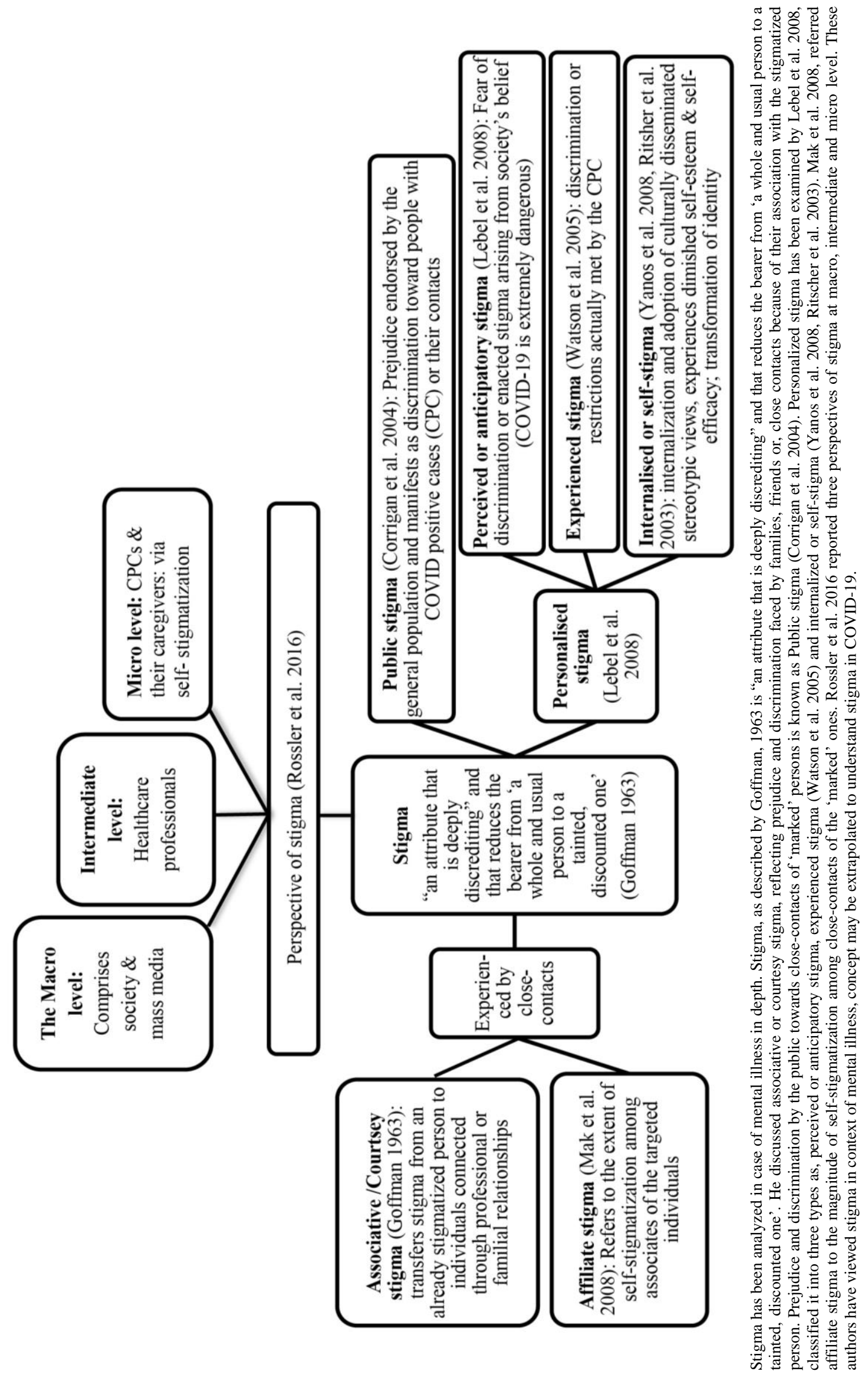


\section{UNDERSTANDING STIGMA IN RELATION TO COVID-19 WITH EXISTING THEORETICAL FRAMEWORKS FOR STIGMA}

\section{Cognitive-behavioral model}

Figure 2 illustrates the cognitive process involved in human behavior in the genesis and propagation of stigma. Situational cues signaled in a specific setting trigger behavioral responses and resultant cognition, which figures out of these cues and behavior as a psychological response (Smith 2002). With inception at Wuhan, China, the infection was entitled "Wuhan virus", "Chinese virus" or "Kung-flu" (Hui 2020). The stigmatized individuals, COVID positive cases (CPC)/ close-contacts, like frontline workers, are devalued as "spreader" (Bagcchi 2020). Often, contagious and chronically disabling diseases are stigmatized. Sufferers are scrutinized as "sinners" or "the cursed ones" or have contracted a disease because of their bad deeds 'karma' (Alam et al. 1997) (Centers for Disease Control and Prevention 2020).

However, there is a flip side of cognitive models of stigma. It pinpoints the "problem" in the person and inclines the cognitive processing of information rather than on the discrimination and exclusion that a stigmatized person experience (Hamilton et al. 2014).

\section{Sociological models}

Over the past five decades, the person's 'social identity' and specific social contexts have garnered attention in conceptualizing stigma. Modified labeling theory (Link \& Phelan 2001) (Figure 3) suggested that stigma exists when a person is identified by a label that sets the person apart and links the person to undesirable stereotypes, separating into groups, and resultant unfair treatment and discrimination (Link et al. 2004). Historically, whenever there has been a lack of explanation, either scientific or supernatural, the affected individuals are labeled, separated, discriminated, and stigmatized (Bhattacharya et al. 2020). By virtue of its novelty, COVID-19 has become a stigmatized disease. COVID-19 hospitals, laboratories, quarantine zones, containment zones, color zones based on the incidence rates, "quarantined' stamps on travelers and quarantined, notices outside homes, are among the few steps implemented to contain the pandemic (Alam et al. 1997). Unfortunately, these initiatives have many social ramifications (Bhattacharya et al. 2020, Menon et al. 2020).

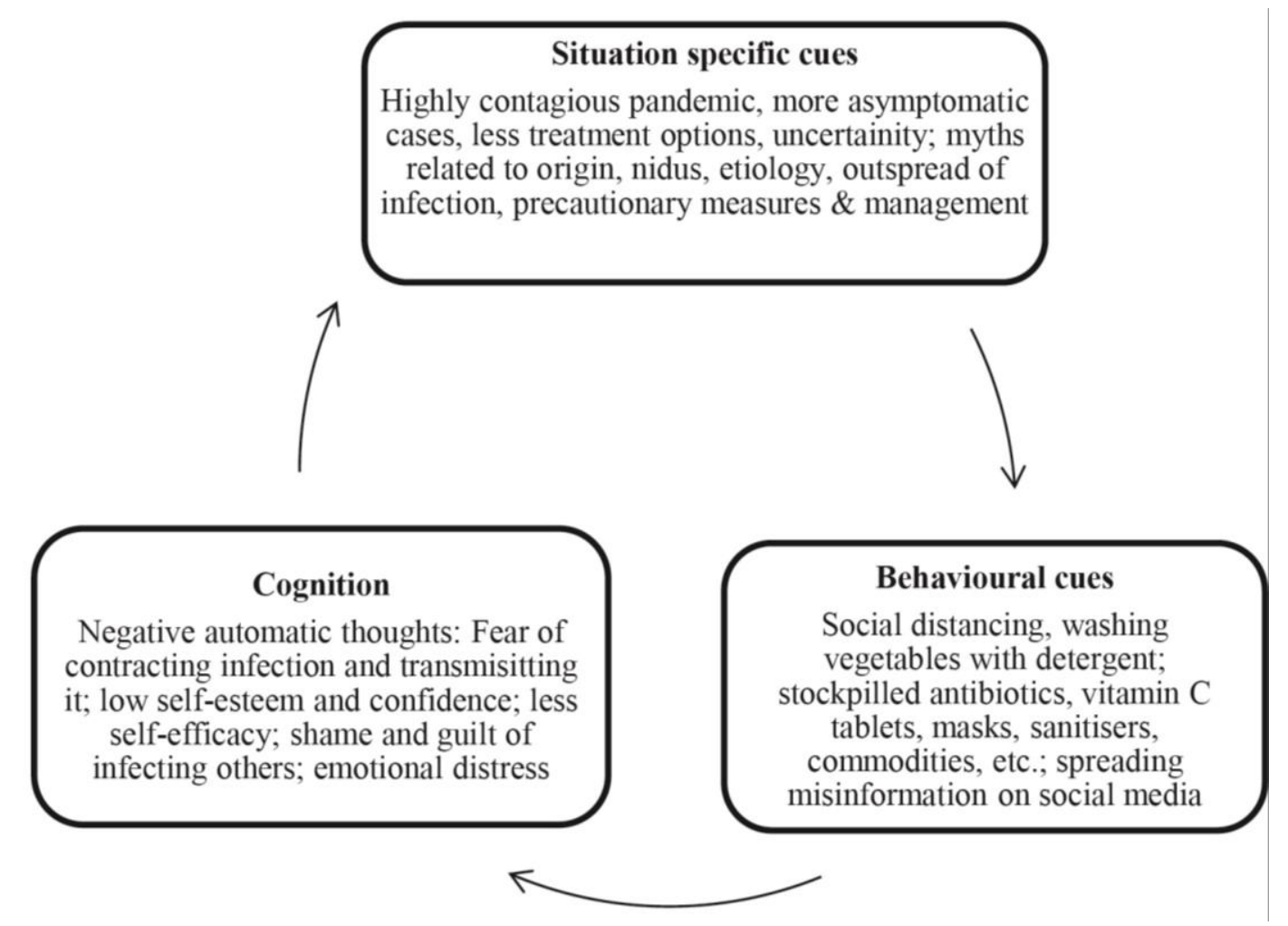

When a person is diagnosed with CPC, socio-cultural ideas associated with the COVID positive status generates negative psychological responses like shame, guilt, embarrassment, demoralization, fear of having transmitting infection to near ones, the worry of own health, consequences on family, etc. This leads to lowered self-esteem, self-confidence, efficacy, etc. Such individuals respond behaviorally by emotionally isolating themselves, collect information and flood social media, etc. Those close by, may start up stocking medications, masks, sanitizers, gloves, etc. as precautions. CPC individuals may feel frustrated and angry about the situation, or the person who has transmitted him, and the close-contacts may have felt that they have been pushed at risk. This leads to a vicious cycle and strengthening of stigma.

Figure-2. Cognitive-behavior model explaining stigma in COVID-19 
Labelling: Group deviated from societal standards and norm due to some undesirable/stigmatizing traits;

$\mathrm{CPC} /$ close-contacts are deviated from the norms due to either "COVID

positive" state or association witht them

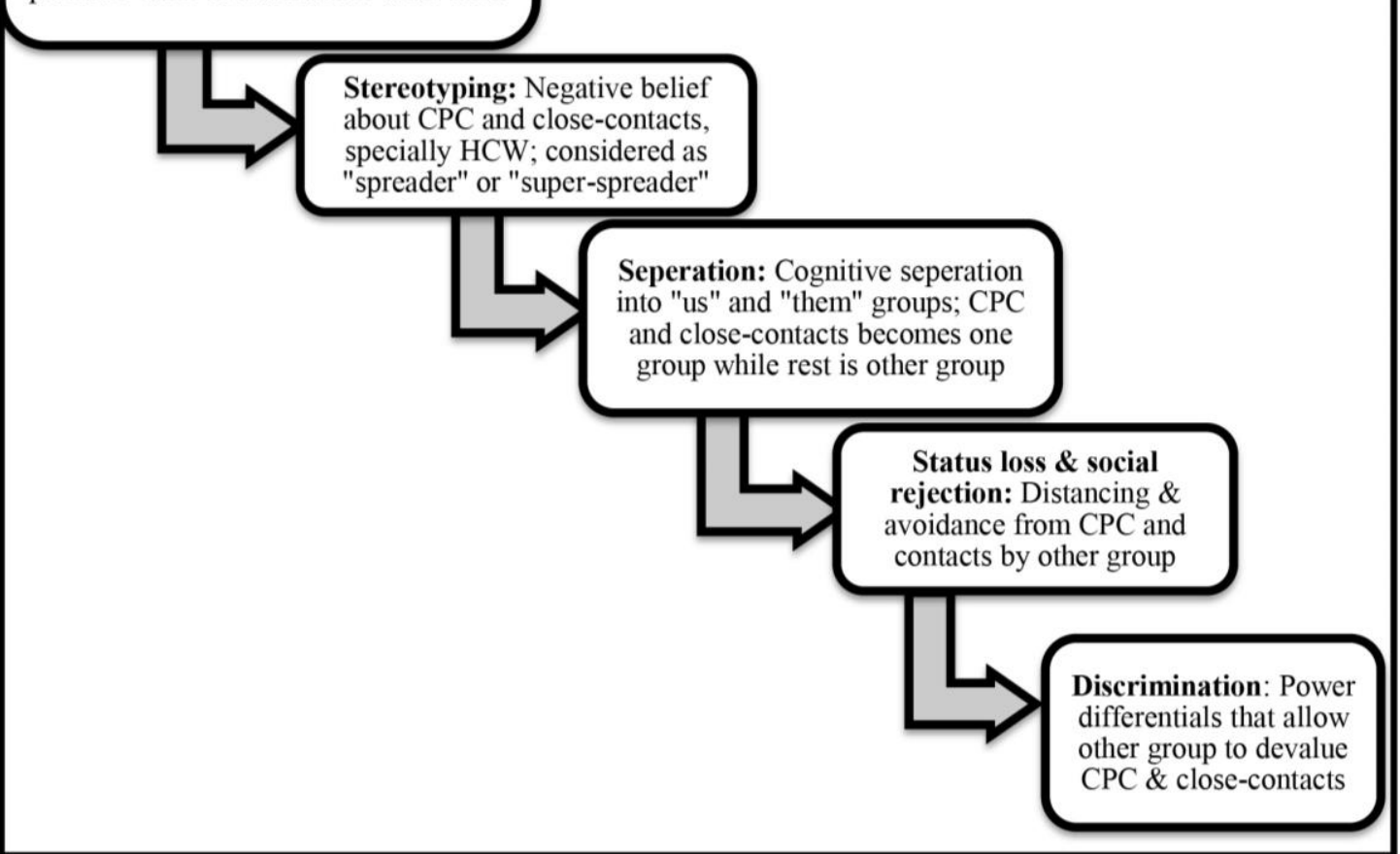

CPC and their close-contacts, like healthcare workers ( $\mathrm{HCW}$ ) are "labeled' with some deviant, "undesirable" stigmatizing trait (like, the culprit of spreading infection or rule-breaker for lockdown or preventive measures). When a person is diagnosed with COVID-19, socio-cultural ideas associated with the CPC are perceived as "different" and labeled. They are considered highly infectious of a "deadly disease with no cure" and hence, a "threat". Stereotypes refer to prefabricated opinions and attitudes (usually in negative connotations) towards members of certain groups, such as the COVID-19 positive group. They are stereotyped with negative believes as "culprit" of breaking 'ethical rules' of the society; and "spreader" or "superspreader" (Ram 2020). Cognitively, two groups are created as CPC and close-contacts while resting other in the second group (separation). They are socially ostracized, may be forced to vacate accommodation, leave employment, harassed, attacked and become a disadvantaged group (Bagcchi 2020, Bhattacharya et al. 2020, Menon et al. 2020). Subsequently, they are separated from society, and lose their social power, get a disgraceful, "spoiled" social identity and status. Another group blames the affected group for transmission of the contagion, based on power and social hierarchy. Finally, they are devalued and discriminated against on either being COVID positive or due to a close association with them.

Figure 3. Modified Labelling theory (Link \& Phelan 2001) to understand stigma in COVID-19

Sartorius, 1997 has proposed a vicious circle of stigma, adapted by Smith 2002 (Figure 4) (permission obtained) (Smith 2002, Sartorius \& Schulze 2005, Sartorius 1997). Thrust of stigma in COVID-19 has been perceived most by frontline workers, healthcare staff and police personnel being "marked" as the carrier of the coronavirus (Bhattacharya et al. 2020, Menon et al. 2020). They have faced violence, harassment, denied access to public transport, abandoned by the family, became "dis-advantaged" due to the "mark" (Bagcchi 2020).

There are six dimensions of stigma (Figure 5) (Jones et al. 1984). High infectivity, unscientific belief, poor understanding about coronavirus in mass, attributing the responsibility of origin in China, has propagated stigma and swept the planet (Bhattacharya et al. 2020, Gladstone 2020). It has also influenced the economic and political world tremendously (Tisdall 2020). Later, this responsibility was handed over to healthcare wor- kers. The social interaction of quarantined and frontline workers has been significantly disrupted. People concealed their foreign travel, workplace as a respite from discrimination and disgust from their community (Bhattacharya et al. 2020, Menon et al. 2020).

\section{A PROPOSED MODEL TO EXPLAIN THE GENESIS AND PROPAGATION OF STIGMA}

Schema is the stable cognitive patterns and specific rules that determine information processing and behavior (Beck \& Beck 2011). Figure 6 demonstrates the formation of the schema for infectious diseases based on past experiences of pandemics/outbreaks. As per the cognitive-emotional-behavior model, during childhood, people develop a 'prism' or "schema" to see an event based on certain ideas about themselves, other people, and their world, as per socio-cultural norms. 


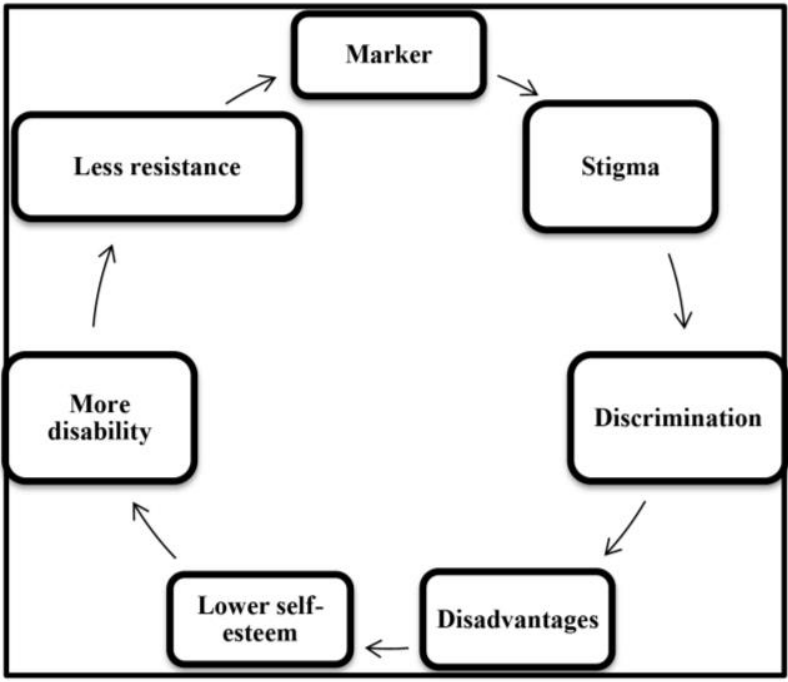

CPC and close-contacts are distinguished with a 'discredit' or a 'label' due to COVID-19 positivity/association with CPC. Afterward, the labeled individuals are stigmatized on the grounds of COVID-19 positivity, considered 'nidus' of infection. This results in the emergence of a feeling of disgust against $\mathrm{CPC} /$ close contacts in public. Subsequently, they are discriminated against and left 'disadvantaged'. Social disadvantage germinates low self-esteem, which increases disability due to restricted access to resources. With lowered selfesteem, they also tend to distance from other groups in the society. As the process progresses, the individual's capacity to combat stigmatization shrinks, and cycle goes on, boosting and ensconcing stigma (Link et al. 2004, Sartorius \& Schulze 2005, Sartorius 1997).

Figure 4. Vicious cycles of stigma, Sartorius, 1997, adapted by Smith, 2002 (permission obtained) (Smith 2002, Sartorius \& Schulze et al. 2005)

These ideas or enduring understandings are 'core beliefs' which are based on the socio-cultural beliefs of family or parents (including myths, misconceptions, rumors, prejudices and stereotypies against an infectious disease outbreak/pandemic), parenting styles, society, peer, school, media, and technology reaction to a situation (Beck \& Beck 2011, Anglin et al. 2011). It is transmitted from one generation to another. These beliefs are so fundamental and deep that they often do not articulate them, even to themselves. The human mind processes an event/situation modulated by their past experience "schema". For every similar event subsequently faced in life, the cognitive information processing is altered and generates "negative automatic thoughts", based on the "schema". These negative automatic thoughts do not rely on or seek deliberation or reasoning. The person starts regarding these ideas as absolute truths. These negative automatic thoughts lead to behavioral, physiological, and emotional consequences and possibly propagate stigmatizing attitudes and corresponding discriminatory behavior (Beck \& Beck 2011, Grusec \& Danyliuk 2014, Corrigan 2002, Anglin et al. 2011).

As illustrated in figure 6, stigma in the COVID-19 pandemic is entangled with mental health literacy, dynamic changes in policies, turmoil in the political world (inter-county dynamics altered, especially with China);

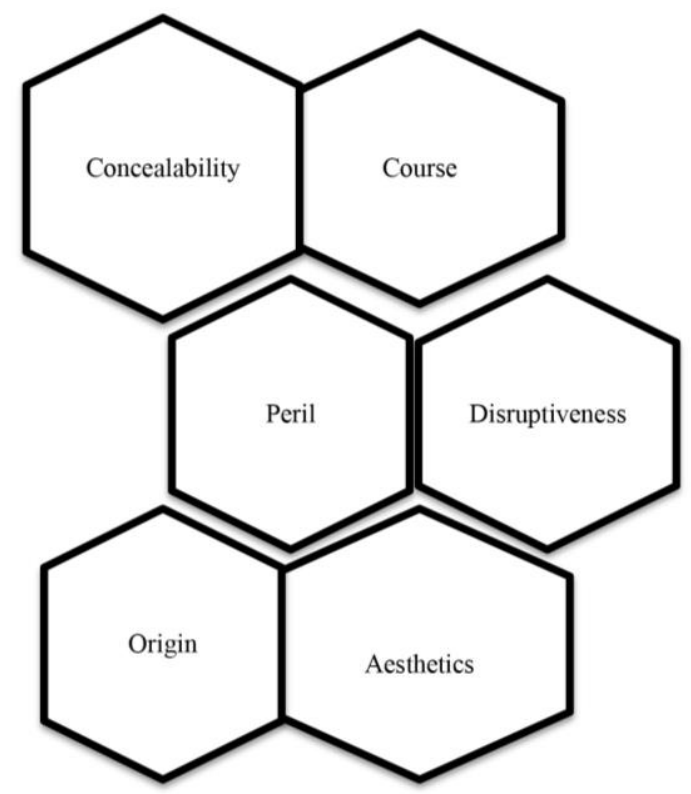

Stigma in an infectious disease like COVID-19 is associated with high infectiousness and potential to transmit the infection to others rapidly, more so in a disease where treatment and outcome are largely unknown. The clouds of uncertainties surround it. Such a disease is seen as a "threat". There are six dimensions of stigma: concealability (the strength to which the difference is apparent), course (greater the irreversibility of the difference, severe is the negative attitude), disruptiveness (the extent to which interpersonal relationships are narrowed), aesthetics (the degree to which a stigmatized individual evokes innate and affective aversion), origin (how the problem started, perceived responsibility for the situation determines how a community responds to the marked culprit) and dangerousness/peril (feelings of danger or threat instigated by the labeled person) (Jones et al. 1984).

Figure-5. Appreciation of dimensions of stigma in COVID-19

revision in medical research and shreds of evidence; with socio-economic-cultural beliefs. Media played a powerful role in the attitude towards this pandemic (Bhattacharya et al. 2020, Menon et al. 2020, Ram 2020). The fusion of pandemic and 'infodemic' made stigma more contagious than COVID-19 itself. Schema, modulated by experiences of previous pandemics and current prevailing scenario, resulted in variegated cognitive distortions like overgeneralization, selective abstraction, dichotomous thinking, and arbitrary inference for genesis and propagation of stigma in the COVID-19 pandemic.

\section{CONCLUSION}

Stigma against COVID-19 has been universally present across the culture. Socio-cultural-economicpolitical factors at cognitive-behavior-emotional level moderate its dimensions and vigor. The effect of stigma persists longer than the infection. Thus, conceptualizing stigma in this pandemic is a priority. Understanding the stigma against COVID-19 from the available models in the literature might pose an issue due to the dynamic nature of factors regulating it. 


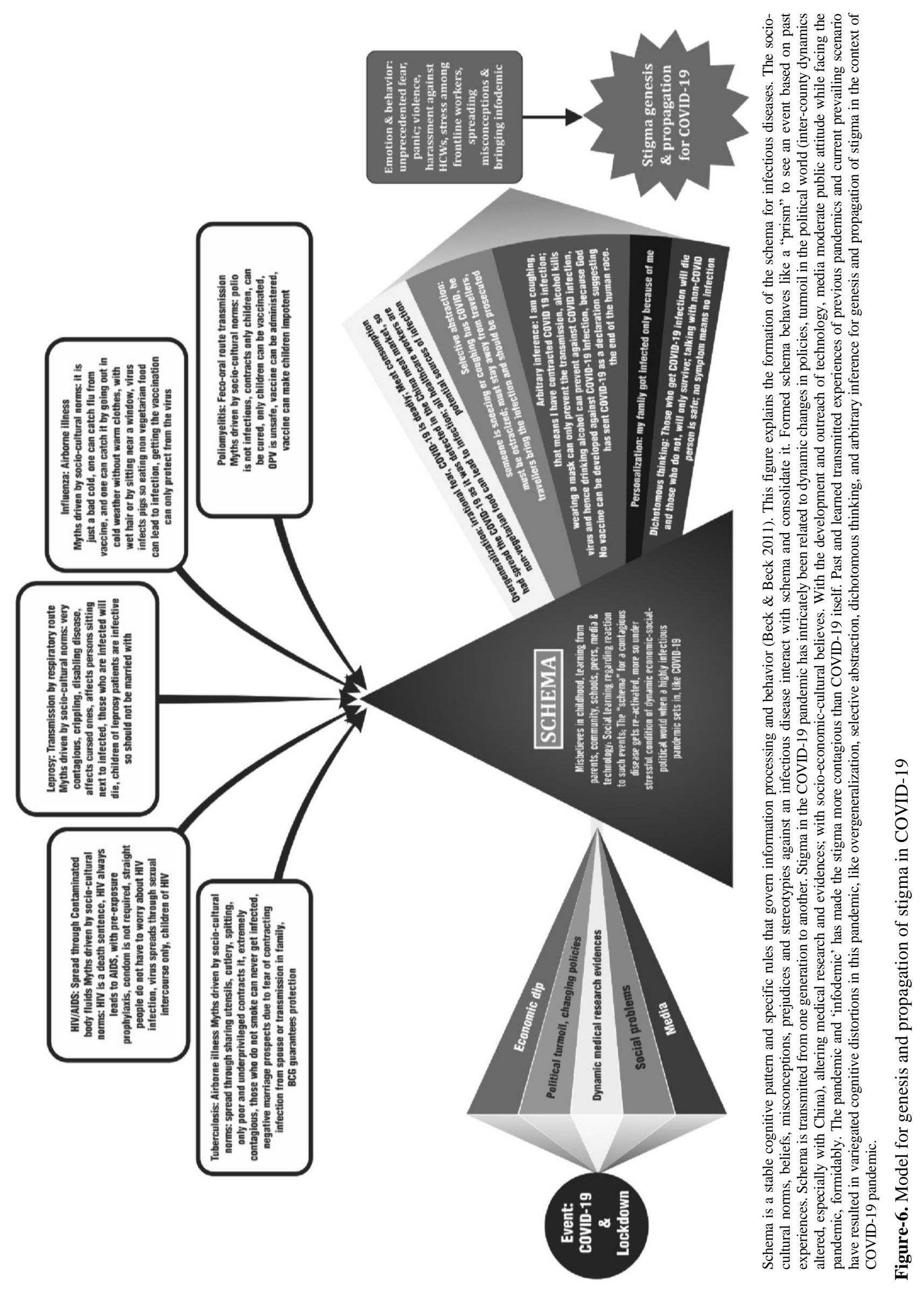


We propose an integrated, comprehensive, and holistic model of stigma. The proposed model intends to give a conceptual framework for the appreciation of its all dimensions and vigor. The model may play a crucial role against stigma in the context of COVID-19, a smoldering issue of paramount public health importance.

\section{Acknowledgements:}

We thank Professor Norman Sartorius (President, Association for the Improvement of Mental Health Programmes (AMH), Switzerland) and Dr. Michael Smith (Associate Medical Director for Mental Health, NHS Greater Glasgow \& Clyde, Glassgow, United Kingdom) for giving us the permission to use the figure of vicious cycle of stigma.

\section{Conflict of interest: None to declare.}

\section{Contribution of individual authors:}

Kumari Rina: Planned and drafted the paper, provided critical revision of the article for intellectual content and final approval of the version to publish.

Vikas Menon: Provided critical revision of the article for intellectual content and final approval of the version to publish

Susanta Kumar Padhy: conceived the idea, provided critical revision of the article for intellectual content and final approval of the version to publish.

\section{References}

1. Alam M, Yunus M, Kalam A, Tahseen M: Social Stigma In Leprosy. Indian J Community Health 1997; 9: 18-20

2. Allport GW: The nature of prejudice unabridged. 25th anniversary Ed. Garden City, New York: Doubleday, Addison-Wesley Publishing Company, 1958

3. Anglin T, Halpern-Felsher B, David KW, Newcomer S: The Science of Adolescent Risk-Taking: Workshop Report.Washington (DC), 2011

4. Bagcchi S: Stigma during the COVID-19 pandemic. Lancet Infect Dis 2020; 20:782

5. Beck JS \& Beck AT: Cognitive conceptualization. In Cognitive Behavior Therapy: Basics and Beyond. 29-45. New York, Guilford Press, 2011

6. Bhattacharya P, Banerjee D \& Rao TS: The "Untold" Side of COVID-19: Social Stigma and Its Consequences in India. Indian J Psychol Med 2020; 42: 382-6

7. Brockington IF, Hall $P$, Levings J, Murphy C: The community's tolerance of the mentally ill. $\mathrm{Br} J$ Psychiatry 1993; 162:93-9

8. CDC Features: World Leprosy Day: Bust the Myths, Learn the Facts Hansen's Disease Myths Busters [Internet]. 2018 Jan 26 [cited on 2020 Dec 20]

9. Available from: https://www.cdc.gov/features/worldleprosy-day/index.html

10. Corrigan $P W \&$ Miller FE: Shame, blame, and contamination: A review of the impact of mental illness stigma on family members. J Ment Health 2004; 13: 537-48

11. Corrigan PW, Druss BG \& Perlick DA: The impact of mental illness stigma on seeking and participating in mental health care. Psychol Sci Public Interes 2014; Suppl.15: 37-70

12. Corrigan PW: Testing Social Cognitive Models of Mental Illness Stigma: The Prairie State Stigma Studies. Psychiatr Rehabil Ski 2002; 6: 232-54.

13. Crocker J, Major B \& Steele C: Social stigma. In: Gilbert D, Fiske ST \& Lindzey G (Eds): The Handbook of Social Psychology. 4th Ed. vol II, 504-53. New York, McGraw-Hill, 1998

14. Earnshaw VA \& Quinn DM: Influenza stigma during the 2009 H1N1 pandemic. J Appl Soc Psychol 2013; 43: E109-14

15. Farina A: Stigma. In: Mueser KT, Tarrier N. (Eds.): Handbook of Social Functioning in Schizophrenia. 24779. Allyn \& Bacon, Needham Heights, Massachusetts, United States, 1998

16. Gladstone R: New York Times [Internet]. Coronavirus Outbreak Risks Reviving Stigma for China. 2020 Feb 10 [cited on 2020 Dec 20].

17. Available from: https://www.nytimes.com/2020/02/10/ world/asia/china-epidemics-coronavirus.html

18. Goffman E: Stigma: Notes on the Management of Spoiled Identity. Englewood Cliffs, New Jersey: PrenticeHall, 1963

19. Grusec JE \& Danyliuk T: Parenting Skills. Parents' Attitudes and Beliefs: Their Impact on Children's Development [Internet]. 2014.

20. Available from: http://www.child-encyclopedia.com/ parenting-skills/according-experts/parents-attitudesand-beliefs-their-impact-childrens-development

21. Gupta S: From 1720 to 2020, Here's List of 4 Worst Pandemics in History That Have Ravaged Humanity [Internet]. $2020 \mathrm{Apr} 3$ [cited on 2020 Nov 18]. India.com

22. Available from: https://www.india.com/news/india/from1720-to-2020-heres-list-of-4-worst-pandemics-inhistory-that-have-ravaged-humanity-3989185/

23. Hamilton S, Lewis-Holmes E, Pinfold V, Henderson C, Rose $D \&$ Thornicroft $G$ : Discrimination against people with a mental health diagnosis: Qualitative analysis of reported experiences. J Ment Health 2014; 23: 88-93.

24. Hui M: Quartz: Why won't WHO use the name SARSCoV-2? [Internet]. 2020 Mar 18 [cited on 2020 Dec 20].

25. Available from: https://qz.com/1820422/coronaviruswhy-wont-who-use-the-name-sars-cov-

2/\#: : text=But\%20despite\%20the\%20virus\%20having, $r$ ead\%20\%E2\%80\%9Ccoronavirus\%20disease\%20virus. $\% E 2 \% 80 \% 9 D$

26. Jones EE, Farina A, Hastorf AH, Markus H, Miller DT \& Scott RE: Social Stigma: The Psychology of Marked Relationships. 347, New York: W H, Guilford Publications, 1984

27. LeBel TP: Perceptions of and Responses to Stigma. Sociol Compass 2008; 2:409-32

28. Link BG \& Phelan CJ: Conceptualizing Stigma. Annual Rev Sociology 2001; 27: 363-85

29. Link BG, Yang LH, Phelan JC, Collins PY: Measuring mental illness stigma. Schizophr Bull 2004; 30: $511-41$

30. Mak $W W$ \& Cheung RYM. Affiliate stigma among caregivers of people with Intellectual disability or mental Illness. J Appl Res Intellect Disabil 2008; 21:532-45

31. Menon V, Padhy SK \& Pattnaik JI: Stigma and Aggression Against Health Care Workers in India Amidst 
COVID-19 Times: Possible Drivers and Mitigation Strategies. Indian J Psychol Med 2020; 42: 400-1

32. Ram T: Branded "super spreader", family of Karnataka COVID-19 victim battles stigma [Intenet]. The News Minute. 2020 May 13 [cited on 2020 Dec 20]

33. Available from: https://www.thenewsminute.com/article/branded-superspreader-family-karnataka-covid-19-victim-battlesstigma-124482

34. Ritsher JB, Otilingam $P G$ \& Grajales $M$. Internalized stigma of mental illness: psychometric properties of a new measure. Psychiatry Res 2003; 121: 31-49

35. Rössler W: The stigma of mental disorders: A millennia-long history of social exclusion and prejudices. EMBO reports 2016; 17:1250-3.

36. Sartorius $N \&$ Schulze H: Reducing the Stigma of Mental Illness: A Report from a Global Programme of the World Psychiatric Association-Reducing the Stigma of Mental Illness. 2005

37. Sartorius N: Fighting schizophrenia and its stigma. A new World Psychiatric Association educational programme. Br J Psychiatry 1997; 170: 297

38. Smith M: Stigma. Adv Psychiatr Treat 2002; 8: 317-23.

39. Stangl AL, Earnshaw VA, Logie CH, Van Brakel W, Simbayi LC, Barré I et al.: The Health Stigma and
Discrimination Framework: A global, crosscutting framework to inform research, intervention development, and policy on health-related stigmas. BMC Med 2019; 17: $18-23$

40. Thornicroft $G$, Rose D, Kassam A, Sartorius N: Stigma: Ignorance, prejudice or discrimination? Br J Psychiatry 2007; 190: 192-3

41. Tisdall S: Power, equality, nationalism: how the pandemic will reshape the world [Internet]. World news: The Guardian. 2020 Mar 28 [cited on 2020 Dec 20].

42. Available from: https://www.theguardian.com/world/ 2020/mar/28/power-equality-nationalism-how-thepandemic-will-reshape-the-world

43. Türközer $H B$ \& Öngür D: A projection for psychiatry in the post-COVID-19 era: potential trends, challenges, and directions. Mol Psychiatry 2020; 25: 2214-9

44. Watson AC \& River LP: A Social-Cognitive Model of Personal Responses to Stigma In Corrigan PW (ed): On the Stigma of Mental Illness: Practical Strategies for Research and Social Change. 145-64, American Psychological Association, 2006

45. Yanos PT, Roe D, Markus K, Lysaker PH: Pathways between internalized stigma and outcomes related to recovery in schizophrenia spectrum disorders. Psychiatr Serv 2008; 59:1437-42

Correspondence:

Prof Susanta Kumar Padhy, MD

Department of Psychiatry, All India Institute of Medical Sciences (AIIMS)

Bhubaneswar, Odisha, 751019, India

E-mail:psych_susanta@aiimsbhubaneswar.edu.in; susanta.pgi30@yahoo.in 